\title{
Tema: Religionshistorie og kulturel evolution
}

Dette nummer af Religionsvidenskabeligt Tidsskrift har en delvis anden type indhold end normalt. Flere af artiklerne angår aktuelle enkeltudgivelser - det drejer sig om Hans J. Lundager Jensens artikler om Robert Bellahs Religion and Human Evolution og om Peter Sloterdijks Du musst dein Leben ändern samt om Anders Klostergaard Petersens artikel om Robert Bellah og Hans Joas, eds., The Axial Age and Its Consequences. Genremæssigt ligger disse redegørende og diskuterende artikler imellem boganmeldelser og 'normale' artikler. Grunden til dette lidt uortodokse valg er, at netop disse bøger har en særstilling, fordi de kan være med til at bevirke en nyorientering af religionshistorien. I samme retning peger en artikel skrevet til dette nummer af den tyske forsker Bernhard Lang; i forlængelse af Bellahs skema for historisk evolution argumenterer han for en særlig fase i religionshistorie, det tidlige agerbrug, ind imellem Bellahs to første faser, tribal religion og arkaisk religion. Langs artikel slutter med en nyttig liste over forskningsbidrag, som forud for, parallelt med og alternativt til Bellahs model diskuterer en evolutionært baseret religionshistorie.

Religionsvidenskabens fagvifte omfatter akademisk velkonsoliderede discipliner som religionssociologi og religionspsykologi samt en mængde mere eller mindre selvstændige retninger, der kan betegnes som sammensætninger eller specifikationer (fx religionsantropologi, -semiotik; kønsforskningsorienteret religionsvidenskab; kognitiv religionsvidenskab). I denne fagvifte er religionshistorien den ældste dimension og den, der historisk har været omdrejningspunktet i etableringen af religionsvidenskaben som akademisk faglighed. Men religionshistorien har også mest været en formel betegnelse for et antal stærkt specialiserede vidensfelter, forankret nationalt eller regionalt, og med lige så tætte eller tættere forbindelser til andre videnskaber og videnskabelige kompetencer, som krævedes for indsigt i de enkelte felter. Traditionelt har filologierne vejet tungt som et obligatorisk vidensfelt. I nutidig religionshistorie kommer dertil uundværlig indsigt i geografi, økonomi, historie, antropologi osv. som forudsætning for indsigt i bestemte områder. Det har betydet, at religionshistorien i praksis er blevet i høj grad regionaliseret og med en relativ svag bevidsthed om fællesskab om en særlig disciplin - ud over fællesskabet omkring et ubestrideligt relevant, men også temmelig elementært sæt af religionsfænomenologiske beskrivelseskategorier. Med andre ord vil 'religionshistorie' i praksis oftest sige fællesmængden af religionshistorierne eller endog punktuelle undersøgel- 
ser af religionsfænomenologisk definerede problemstillinger inden for konkrete, kulturelle kontekster. Med Robert Bellahs bog fra 2011 præsenteres herimod en vision om religionens historie, der kan samle indsigter, fordelt ud i de regionale vidensfelter, og transformere dem til en egentlig religionshistorie. Bellahs bog fortæller religionens historie fra begyndelsen, men kun op til 'aksetiden', dvs. til den periode i århundrederne omkring midten af 1 . årt. f.Kr., hvor de intellektuelle retninger, der kommer til at præge Kina, Indien og Europa op til nutiden, danner sig og træder frem - med en ejendommelig og endnu vanskelig forståelig samtidighed. Sloterdijks bog er ganske vist skrevet helt uafhængigt af Bellahs og med et andet sigte. Men dens fortælling begynder præcist, hvor Bellah slutter, og den kan derfor også læses som et bud på en fortælling om den religionshistoriske udvikling fra aksetiden til nutiden og ind $i$ fremtiden.

Da dette nummer af Religionsvidenskabeligt Tidsskrift var under udarbejdelse, kom meddelelsen om Robert Bellahs død 30. juli. Nummeret her er ikke tænkt som et temanummer om Bellah, for hans berettigede berømmelse skyldes hans undersøgelser over religion i nutiden, mere end hans kulturevolutionære teori, og en dækkende præsentation ville have inkluderet diskussioner af nyklassikerne om Habits of the Heart og om civilreligion. Men da det er Bellahs indsats, som er et naturligt udgangspunkt for den aktuelle debat, som dette nummer gerne vil befordre, er det naturligt at markere afslutningen af en fremragende religionsvidenskabelig karriere. Religionssociologen Lene Kühle har venligt indvilliget $\mathrm{i}$ at skrive en nekrolog.

Nummeret her rummer også andet stof. Marie Kallestrup Laursen genoptager diskussionen om det fortsat relevante og uafklarede problem: det, den store religionsforsker Georges Dumézil kaldte den indoeuropæiske, trefunktionelle ideologi, altså en kulturspecifik forestilling, nedarvet i et antal historiske samfund sammen med den sproghistoriske arv, trods disse samfunds geografiske og kulturelle forskelligheder i øvrigt. If. tankegangen, 'ideologien', kan en i princippet åben række menneskelige aktivitetsfelter, begyndende med samfundets organisering, analyseres som samarbejdet imellem suverænitetsudøvelse, kamp og frugtbarhedsfrembringelse. Artiklen ønsker at give den historisk-deskriptive diskussion en ny fundering i aktuel forskning i kulturel hukommelse, narrativitet og normativ kognition. Ad denne vej kan der gives en mere plausibel forklaring end hidtil på, hvordan denne ideologi kunne bevares igennem lange tidsrum og stor geografisk spredning.

Også dette nummer af tidsskriftet rummer anmeldelser af aktuel litteratur. Anders Klostergaard Petersen giver en fyldig omtale af to bind af den nye Platonoversættelse. Spørgsmålet om 'den historiske Jesus', et emne med forbindelse til kulturel evolution, behandles i to bøger, der anmeldes af hhv. Klostergaard Petersen og Ole Davidsen. Nummeret her afsluttes med et antal yderligere anmeldelser.

Redaktionen 